\title{
Optimal Zn-Modified Ca-Si-Based Ceramic Nanocoating with Zn Ion Release for Osteoblast Promotion and Osteoclast Inhibition in Bone Tissue Engineering
}

\author{
Jiangming Yu, ${ }^{1,2}$ Lizhang Xu, ${ }^{1}$ Ning Xie, ${ }^{1}$ Kai Li, ${ }^{3}$ Yanhai Xi, ${ }^{1}$ Xiling Liu, ${ }^{1}$ \\ Xuebin Zheng, ${ }^{3}$ Xiongsheng Chen, ${ }^{1}$ Xiaojian Ye, ${ }^{1}$ and Daixu Wei ${ }^{4}$ \\ ${ }^{1}$ Department of Orthopaedics, Changzheng Hospital, Second Military Medical University, Shanghai 200003, China \\ ${ }^{2}$ National Engineering Research Center for Nanotechnology, Shanghai 200241, China \\ ${ }^{3}$ Key Laboratory of Inorganic Coating Materials, Shanghai Institute of Ceramics, Chinese Academy of Sciences, \\ Shanghai 200003, China \\ ${ }^{4}$ Tsinghua-Peking Center for Life Sciences, Tsinghua University, Beijing 100084, China
}

Correspondence should be addressed to Xiaojian Ye; yespine@163.com and Daixu Wei; daviddxwei@163.com

Received 21 December 2016; Revised 21 January 2017; Accepted 30 January 2017; Published 9 March 2017

Academic Editor: Chuanfei Guo

Copyright (C) 2017 Jiangming Yu et al. This is an open access article distributed under the Creative Commons Attribution License, which permits unrestricted use, distribution, and reproduction in any medium, provided the original work is properly cited.

\begin{abstract}
We investigated the slow release of $\mathrm{Zn}$ ion $\left(\mathrm{Zn}^{2+}\right)$ from nanocoatings and compared the in vitro response of osteoblasts (MC3T3E1) and proosteoclasts (RAW 264.7) cultured on $\mathrm{Ca}_{2} \mathrm{ZnSi}_{2} \mathrm{O}_{7}$ nanocoated with different $\mathrm{Zn} / \mathrm{Ca}$ molar ratios on a Ti-6Al-4V (i.e., Ti) substrate to optimize cell behaviors and molecule levels. Significant morphology differences were observed among samples. By comparing with pure $\mathrm{Ti}$ and $\mathrm{CaSiO}_{3}$ nanocoating, the morphology of $\mathrm{Ca}_{2} \mathrm{ZnSi}_{2} \mathrm{O}_{7}$ ceramic nanocoatings was rough and contained small nanoparticles or aggregations. Slow $\mathrm{Zn}^{2+}$ release from nanocoatings was observed and $\mathrm{Zn}^{2+}$ concentration was regulated by varying the $\mathrm{Zn} / \mathrm{Ca}$ ratios. The cell-response results showed $\mathrm{Ca}_{2} \mathrm{ZnSi}_{2} \mathrm{O}_{7}$ nanocoating at different $\mathrm{Zn} / \mathrm{Ca}$ molar ratios for osteoblasts and osteoclasts. Compared to other nanocoatings and $\mathrm{Ti}$, sample $\mathrm{Zn} / \mathrm{Ca}(0.3)$ showed the highest cell viability and upregulated expression of the osteogenic differentiation genes ALP, COL-1, and OCN. Additionally, sample Zn/Ca (0.3) showed the greatest inhibition of RAW 264.7 cell growth and decreased the mRNA levels of osteoclast-related genes OAR, TRAP, and HYA1. Therefore, the optimal $\mathrm{Zn}$-Ca ratio of 0.3 in $\mathrm{Ca}_{2} \mathrm{ZnSi}_{2} \mathrm{O}_{7}$ ceramic nanocoating on Ti had a dual osteoblast-promoting and osteoclast-inhibiting effect to dynamically balance osteoblasts/osteoclasts. These optimal $\mathrm{Zn}$-Ca ratios are valuable for $\mathrm{Ca}_{2} \mathrm{ZnSi}_{2} \mathrm{O}_{7}$ ceramic nanocoating on Ti-coated implants for potential applications in bone tissue regeneration.
\end{abstract}

\section{Introduction}

In bone tissue engineering, calcium silicate-based ceramics, such as $\mathrm{CaSiO}_{3}$ and $\mathrm{Ca}_{2} \mathrm{SiO}_{4}$, are promising as potential implant biomaterials based on their bioactive and biocompatible properties $[1,2]$. Recently, novel ion-modified $\mathrm{Ca}-$ Si-based ceramics were developed to improve their chemical stability and biomedical properties. Introduced ions mainly include divalent (e.g., $\mathrm{Zn}, \mathrm{Mg}$, and Sr) [3-5] and tetravalent (e.g., $\mathrm{Zr}$ and $\mathrm{Ti}$ ) ions $[6,7]$. Compared with pure calcium silicate coatings, tetravalent $\mathrm{Ti}$ and $\mathrm{Zr}$-incorporated $\mathrm{Ca}-\mathrm{Si}$ based ceramics have been used as stable coatings to improve biomedical properties.
Zinc $(\mathrm{Zn})$, an essential trace element, has been demonstrated to play an important role in various physiological processes in humans [8]. However, Zn-modified calcium silicate ceramic coatings have not been widely investigated. $\mathrm{Zn}$ was shown to have a stimulatory effect on bone formation and inhibitory or biphasic effect on osteoclastic bone resorption [9]. Furthermore, $\mathrm{Zn}$ deficiency in the body can arrest bone growth, bone development, and overall bone health maintenance [10]. However, Zn-modified calcium silicate $\left(\mathrm{Ca}_{2} \mathrm{ZnSi}_{2} \mathrm{O}_{7}\right)$ ceramic coating $\mathrm{Ti}$ shows high potential as a biomaterial in bone tissue engineering but has not been investigated in detail. 
Previous studies [11, 12] investigated the preparation of $\mathrm{Ca}_{2} \mathrm{ZnSi}_{2} \mathrm{O}_{7}$ ceramic nanocoating on a Ti-6Al-4V (i.e., $\mathrm{Ti}$ ) substrate and explored the effects on osteoblasts. The results showed that the $\mathrm{Ca}_{2} \mathrm{ZnSi}_{2} \mathrm{O}_{7}$ nanocoating promoted the adhesion, proliferation, and osteoblast differentiation of MC3T3-E1 cells. However, the optimal $\mathrm{Zn}$ content in the $\mathrm{Ca}_{2} \mathrm{ZnSi}_{2} \mathrm{O}_{7}$ nanocoating and whether abundant healthy osteoblasts grew on the $\mathrm{Zn}$ nanocoating were not confirmed. Various materials can affect osteoclasts when stimulating osteoblasts because of the dynamic balance between these cells $[13,14]$. Moreover, we predicted that $\mathrm{Zn}$ ion could be released slowly from the $\mathrm{Ca}_{2} \mathrm{ZnSi}_{2} \mathrm{O}_{7}$ ceramic nanocoating to maintain the $\mathrm{Zn}^{2+}$ content for MC3T3-E1 cells in the medium. Therefore, in this study, we investigated the optimal $\mathrm{Zn} / \mathrm{Ca}$ ratio in $\mathrm{Ca}_{2} \mathrm{ZnSi}_{2} \mathrm{O}_{7}$ nanocoating and the slow release of $\mathrm{Zn}$ from the nanocoating to promote osteogenic differentiation and inhibit osteoclastic differentiation.

\section{Materials and Methods}

2.1. Materials. Zinc nitrate hexahydrate was purchased from Sinopharm Chemical Reagent Co., Ltd. (Shanghai, China). Calcium nitrate tetrahydrate and tetraethyl orthosilicate were purchased from Sinopharm Chemical Reagent Co., Ltd. Ti$6 \mathrm{Al}-4 \mathrm{~V}$ substrates were fabricated in our lab. All cell culture reagents were purchased from Life-Tech Co., Ltd. (USA), and cell culture plates were obtained from Corning (Corning, NY, USA). Other analytical grade reagents were purchased from Sigma (St. Louis, MO, USA) and Milli-Q water was produced in our lab.

2.2. Preparation of Nanocoatings. According to previous studies [11, 12], three types of zinc-modified calcium silicate $\left(\mathrm{Ca}_{2} \mathrm{ZnSi}_{2} \mathrm{O}_{7}\right)$ powders and nanocoatings were prepared. Briefly, using zinc nitrate hexahydrate, calcium nitrate tetrahydrate, and tetraethyl orthosilicate, nanoscale $\mathrm{Ca}_{2} \mathrm{ZnSi}_{2} \mathrm{O}_{7}$ powders were synthesized by the sol-gel method. These powders had different $\mathrm{Zn} / \mathrm{Ca}$ molar ratios of 0.1 , 0.3 , and 0.5 , respectively, and were named as samples $\mathrm{Zn} / \mathrm{Ca}(0.1), \mathrm{Zn} / \mathrm{Ca}(0.3)$, and $\mathrm{Zn} / \mathrm{Ca}(0.5)$. The produced $\mathrm{Ca}_{2} \mathrm{ZnSi}_{2} \mathrm{O}_{7}$ powders were sprayed onto Ti-6Al-4V substrates with dimensions of $10 \times 10 \times 2 \mathrm{~mm}$ and $ø 10 \times 1 \mathrm{~mm}$. To prepare all nanocoatings, the atmosphere plasma spray (APS) system (Sulzer Metco, Winterthur, Switzerland) was employed to generate a coating thickness of approximately $170 \mathrm{~mm}$. $\mathrm{CaSiO}_{3}$ coatings were prepared using pure $\mathrm{CaSiO}_{3}$ nanopowder, named as sample $\mathrm{Zn} / \mathrm{Ca}(0)$, because of the lack of the $\mathrm{Zn}$ element. After spraying, all samples, including Ti$6 \mathrm{Al}-4 \mathrm{~V}$ substrates (named as sample $\mathrm{Ti}$ ) as a control, were ultrasonically cleaned in acetone, ethanol, and distilled water for $10 \mathrm{~min}$.

2.3. Characterizations of Nanocoatings. Morphological studies of all samples were performed by scanning electron microscopy (SEM) (Hitachi S-4800, Tokyo, Japan). All samples were treated by $\mathrm{Pt}$ spraying for $60 \mathrm{~s}$ prior to observation at $10 \mathrm{x}$ and $5000 \mathrm{x}$ magnification by SEM at $10 \mathrm{kV}$. In addition, the static contact angles of all nanocoatings were measured using a contact angle analyzer (Model SL600; Solon Inform-tech Co. Ltd., Shanghai, China) at $25^{\circ} \mathrm{C}$. Next, $5 \pm 0.5 \mu \mathrm{L}$ of Milli-Q water was gently added onto the surface of each sample and measured within $10 \mathrm{~s}$. For statistical analysis, the static contact angles were evaluated for at least 6 random contact test points.

2.4. In Vitro Release Studies of $\mathrm{Zn}^{2+}$. Two divalent ions of $\mathrm{Zn}^{2+}$ were studied for in vitro release from the nanocoatings. All samples were immersed in $20 \mathrm{~mL}$ alpha-minimum essential medium ( $\alpha$-MEM) for 7 days and then filtered through a $0.22 \mu \mathrm{m}$ membrane (Millipore, Billerica, MA, USA). The test media were diluted $1 / 20$ prior to measurement. The concentration of $\mathrm{Zn}^{2+}$ was detected using an inductively coupled plasma atomic emission spectrometer (ICP-AES, 710-ES, Varian Medical Systems, Palo Alto, CA, USA). Sample Ti without nanocoatings as a control was also analyzed in the same manner for release studies in vitro.

2.5. Cell Culture. Osteoblasts (MC3T3-E1) and proosteoclasts (RAW 264.7) were kindly provided by Shanghai Cell Bank in the Chinese Academy of Sciences. The MC3T3-E1 cells and RAW 264.7 cells, respectively, were cultivated in the $\alpha$-MEM with penicillin/streptomycin (both 100 units/mL), and $10 \%$ of fetal beef serum (FBS) in incubator was supplied with 5\% of $\mathrm{CO}_{2}$ at $37^{\circ} \mathrm{C}$. The $\alpha$-MEM for RAW 264.7 cells contained $10 \mathrm{ng} / \mathrm{mL}$ RANKL for osteoclastic differentiation [13].

2.6. CCK-8 Test. In the cell proliferation test, $2 \times 10^{4} \mathrm{MC} 3 \mathrm{~T} 3-$ E1 cells and RAW 264.7 cells were, respectively, seeded onto the surface of discs sterilized with $75 \% \mathrm{v} / \mathrm{v}$ ethyl alcohol for $6 \mathrm{~h}$ and UV for $2 \mathrm{~h}$. The cells on samples were cultivated in $\alpha$-MEM at day 3 and day 7 , respectively, and viability was assessed by the CCK- 8 assay (Cell Counting Kit-8, Sigma). Briefly, the original $\alpha$-MEM was replaced with $500 \mu \mathrm{L}$ of fresh $\alpha$-MEM containing $10 \%$ CCK-8. Osteoblast cells on films with CCK- 8 were incubated at $37^{\circ} \mathrm{C}$ for $1 \mathrm{~h}$ to form dissoluble formazan. Next, $100 \mathrm{~mL}$ of dissoluble formazan was removed from each sample and added to the well in a 96-well plate, which was analyzed in a microplate reader (SpectraMax M4, Molecular Devices, Sunnyvale, CA, USA) at $450 \mathrm{~nm}$.

2.7. Confocal Laser Scanning Microscope (CLSM). To analyze cell numbers, at day 3 and day 7 , cells on the samples were treated with $10 \%(\mathrm{w} / \mathrm{v})$ paraformaldehyde for $15 \mathrm{~min}$, $0.5 \%(\mathrm{w} / \mathrm{v})$ Triton X-100 for $20 \mathrm{~min}$, and then DAPI and Phalloidin-Alexa Fluor $^{\circledR} 488$ (for RAW 264.7 cell) and Phalloidin-Alexa Fluor 555 (MC3T3-E1 cell) in $30 \mathrm{~min}$. Next, the cells were observed by confocal laser scanning microscopy (CLSM, TCS SP5, Leica, Wetzlar, Germany).

2.8. Scanning Electron Microscopy (SEM). At day 7, the cells on samples were also dehydrated in a graded ethanol series of $50 \%, 60 \%, 70 \%, 80 \%, 85 \%, 90 \%, 95 \%$, and $100 \%(\mathrm{v} / \mathrm{v})$ for $15 \mathrm{~min}$ and then treated by freeze-drying to remove residual ethanol for $4 \mathrm{~h}$. Finally, the cells sprayed with Pt for $120 \mathrm{~s}$ were evaluated by SEM at 250x magnification. 
TABLE 1: Primers used for Sybr Green polymerase chain reaction (RT-PCR) in this study.

\begin{tabular}{|c|c|}
\hline Genes & Primers \\
\hline \multirow{2}{*}{ OAR } & Forward: $5^{\prime}$-CGTGCTGACTTCACACCAACA-3' \\
\hline & Reverse: 5'-AAGGTCACGTTGATCCCAGGAG-3' \\
\hline \multirow{2}{*}{ TRAP } & Forward: 5'-GTGCTGGCTGGAAACCATGA-3' \\
\hline & Reverse: $5^{\prime}$-GTCCAGCATAAAGATGGCCACA-3' \\
\hline \multirow{2}{*}{ HYA1 } & Forward: 5'-CCGTAATGCCCTACGTCCAG-3' \\
\hline & Reverse: 5'-AAGGGCCCAAGTGTGGAA- $3^{\prime}$ \\
\hline \multirow{2}{*}{ COL1 } & Forward: $5^{\prime}$-GCGAAGGCAACAGTCGCT-3' \\
\hline & Reverse: 5'-CTTGGTGGTTTTGTATTCGATGAC-3' \\
\hline \multirow{2}{*}{ ALP } & Forward: $5^{\prime}$-TCCTGACCAAAAACCTCAAAGG-3' \\
\hline & Reverse: 5'-TGCTTCATGCAGAGCCTGC-3' \\
\hline \multirow{2}{*}{$\mathrm{OCN}$} & Forward: 5'-CTCACAGATGCCAAGCCCA- $3^{\prime}$ \\
\hline & Reverse: $5^{\prime}$-CCAAGGTAGCGCCGGAGTCT-3' \\
\hline \multirow{2}{*}{ GAPDH } & Forward: $5^{\prime}$ - TCCACTCACGGCAAATTCAACG - $3^{\prime}$ \\
\hline & Reverse: 5' - TAGACTCCACGACATACTCAGC-3' \\
\hline
\end{tabular}

2.9. Real-Time Quantitative PCR (RT-qPCR). Using the Quantitect SYBR Green PCR Kit (Qiagen, Hilden, Germany), the expression of 3 osteogenic gene markers for MC3T3E1, alkaline phosphatase (ALP), collagen type-1 (COL-1), and osteocalcin (OCN), was evaluated by real-time quantitative PCR (RT-qPCR) [15]. The primers used are shown in Table 1. First, $1 \mathrm{mg}$ of the total RNA from the cells on each film was purified for the synthesis of complementary DNA according to the kit instructions. Similarly, the expression of 3 osteoclastic gene markers for RAW 264.7 cells, osteoclast-associated receptor (OAR), tartrate-resistant acid phosphatase (TRAP), and hyaluronoglucosaminidase 1 (HYA1), was evaluated by the same method. The results were reported as the relative expression normalized to the transcript level of the housekeeping gene glyceraldehyde 3phosphate dehydrogenase (GAPDH).

2.10. Statistical Analysis. For statistical analysis, all data were expressed as the means \pm standard deviations (SD) $(n=3-6)$. Statistical comparisons were performed by Student's $t$-tests with $p<0.05$ indicating statistical significance and $p<0.01$ indicating high statistical significance.

\section{Results and Discussion}

3.1. Characterization of $\mathrm{Ca}_{2} \mathrm{ZnSi}_{2} \mathrm{O}_{7}$ Nanocoatings. Metals are widely considered to be optimal materials for bone repair in bone tissue engineering because of their physical characteristics, which are similar to those of natural bone. However, traditional metallic biomaterials, for example, titanium alloy, did not show a satisfactory cellular response and ultimately did not show tissue regeneration when implanted in the body for a long period of time, limiting their applications. Thus, studies to modify the surfaces of metallic biomaterials attempted to improve their wear properties, corrosion resistance, and biocompatibility [16-18]. In previous studies $[11,12]$, we verified that $\mathrm{Ca}_{2} \mathrm{ZnSi}_{2} \mathrm{O}_{7}$ nanocoating promoted the adhesion, proliferation, and osteoblast differentiation of MC3T3-E1 cells. However, the optimal $\mathrm{Zn}$ content in $\mathrm{Ca}_{2} \mathrm{ZnSi}_{2} \mathrm{O}_{7}$ nanocoating and whether healthy osteoblasts grow abundantly on $\mathrm{Zn}$ in the nanocoating were not confirmed. Moreover, we predicted that $\mathrm{Zn}^{2+}$ could be released slowly from the $\mathrm{Ca}_{2} \mathrm{ZnSi}_{2} \mathrm{O}_{7}$ ceramic nanocoating to maintain a reasonable $\mathrm{Zn}^{2+}$ content for MC3T3-E1 cells in the medium, which is similar to the sustained release system of $\mathrm{Zn}^{2+}$.

First, we regulated the $\mathrm{Zn} / \mathrm{Ca}$ ratios in the $\mathrm{Ca}_{2} \mathrm{ZnSi}_{2} \mathrm{O}_{7}$ ceramic nanocoating. As shown in Figure 1, the micromorphology of the samples with ceramic nanocoatings was rough (Figures 1(b)-1(e)), which was different from the Ti substrate (Figure 1(a)). Some ceramic big particles, which are labeled by blue arrows in Figure 1, were observed on surface of $\mathrm{Zn} / \mathrm{Ca}$ (0) and additional nanoparticles or aggregations adhered on the nanocoatings of $\mathrm{Ca}_{2} \mathrm{ZnSi}_{2} \mathrm{O}_{7}$ (red arrows in Figure 1). These results were similar to those of previous studies [11]. However, with increasing $\mathrm{Zn}$ content in the nanocoating, the surface nanoparticles decreased gradually from $\mathrm{Zn} / \mathrm{Ca}$ (0.1) to $\mathrm{Zn} / \mathrm{Ca}(0.5)$. Similarly, sizes distribution of surface particles also showed a decreasing tendency, and average sizes of $\mathrm{Zn} / \mathrm{Ca}(0), \mathrm{Zn} / \mathrm{Ca}(0.1), \mathrm{Zn} / \mathrm{Ca}(0.3)$, and $\mathrm{Zn} / \mathrm{Ca}(0.5)$ are $401 \pm 195 \mathrm{~nm}, 212 \pm 47 \mathrm{~nm}, 178 \pm 61 \mathrm{~nm}$, and $119 \pm 67 \mathrm{~nm}$, respectively. These results indicate that $\mathrm{Zn}$ content changed the structure of the ceramic nanocoatings. Interestingly, the introduction of $\mathrm{Zn}$ did not affect the surface hydrophilicity of the coatings, as measured by the water contact angle test. As shown in Figure 2, the water contact angles of $\mathrm{Zn} / \mathrm{Ca}(0.1)$, $\mathrm{Zn} / \mathrm{Ca}(0.3)$, and $\mathrm{Zn} / \mathrm{Ca}(0.5)$ were $18.31^{\circ}$ to $21.22^{\circ}$, which are close to $21.49^{\circ}$ of $\mathrm{Zn} / \mathrm{Ca}(0)$, representing the $\mathrm{CaSiO}_{3}$ coating. But all nanocoatings showed lower water contact angles than control $\mathrm{Ti}$ of $39.86^{\circ}$. Thus, these nanocoatings changed the surface physical property by transforming the microstructures. However, different $\mathrm{Zn} / \mathrm{Ca}$ ratios among the nanocoatings did not have a large effect on surface hydrophilicity.

3.2. Release of $\mathrm{Zn}^{2+}$ from Nanocoatings. Furthermore, the influence of the potential slow release of $\mathrm{Zn}$ from the nanocoatings was evaluated. As shown in Figure $3, \mathrm{Zn}^{2+}$ showed typical slow release from the nanocoatings of $\mathrm{Ca}_{2} \mathrm{ZnSi}_{2} \mathrm{O}_{7}$ with different $\mathrm{Zn} / \mathrm{Ca}$ ratios, with a burst release in the initial $12 \mathrm{~h}$. Ultimately, with increasing $\mathrm{Zn}$ content in the nanocoatings, the order of accumulated $\mathrm{Zn}^{2+}$ concentration in the medium was $\mathrm{Ti}=\mathrm{Zn} / \mathrm{Ca}(0)<\mathrm{Zn} / \mathrm{Ca}(0.1)$ $<\mathrm{Zn} / \mathrm{Ca}(0.3)<\mathrm{Zn} / \mathrm{Ca}(0.5)$. The contents of $\mathrm{Zn} / \mathrm{Ca}(0.1)$, $\mathrm{Zn} / \mathrm{Ca}(0.3)$, and $\mathrm{Zn} / \mathrm{Ca}(0.5)$ were $3.12,5.89$, and $9.41 \mathrm{ppm}$, respectively. In contrast, released $\mathrm{Zn}^{2+}$ from sample $\mathrm{Zn} / \mathrm{Ca}$ (0), representing $\mathrm{Ca}_{2} \mathrm{SiO}_{3}$, was close to 0 , similarly to sample Ti. In previous studies [19-22], Zn, an important element in cells and the body, was introduced into an inorganic compound coating, such as hydroxyapatite (HA). To improve the osseointegration properties of the hydroxyapatite-titanium substrate $\left(\mathrm{HA} / \mathrm{TiO}_{2}\right)$, Zhang et al. prepared $\mathrm{Zn}$ containing hydroxyapatite titania $\left(\mathrm{ZnHA} / \mathrm{TiO}_{2}\right)$ hybrid coatings on titanium, and the released $\mathrm{Zn}^{2+}$ was investigated [22]. However, $\mathrm{Zn}$ was only mixed into the microporous structure 
$\mathrm{Ti}$
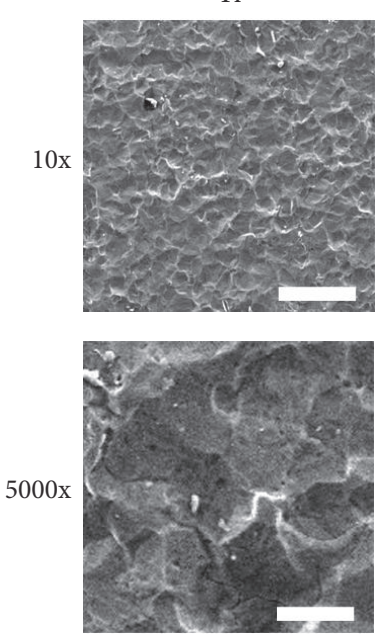

(a)
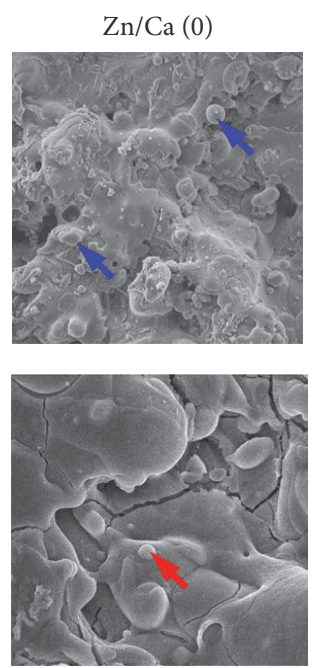

(b)
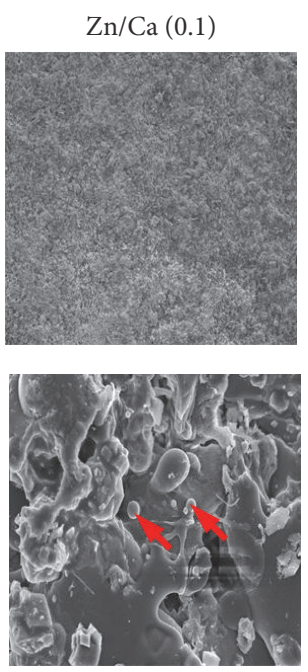

(c)
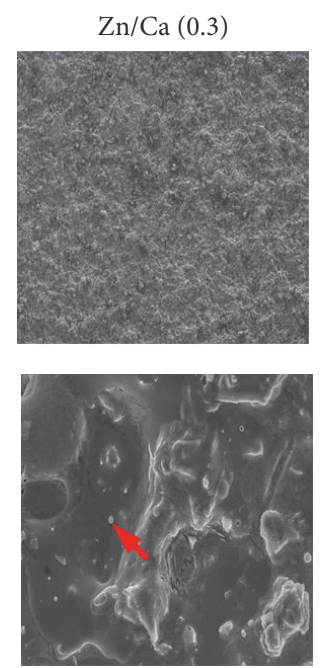

(d)
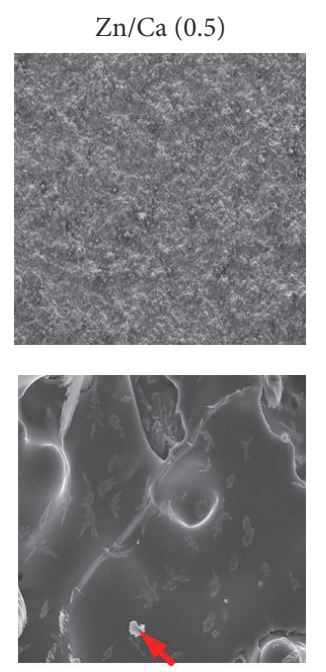

(e)

Figure 1: Morphology of Ti, $\mathrm{Zn} / \mathrm{Ca}(0), \mathrm{Zn} / \mathrm{Ca}(0.1), \mathrm{Zn} / \mathrm{Ca}(0.3)$, and $\mathrm{Zn} / \mathrm{Ca}(0.5)$, respectively. The bar is $1 \mathrm{~mm}$ in $10 \mathrm{x}$ magnification and the bar is $2 \mu \mathrm{m}$ in 5000x magnification, respectively.

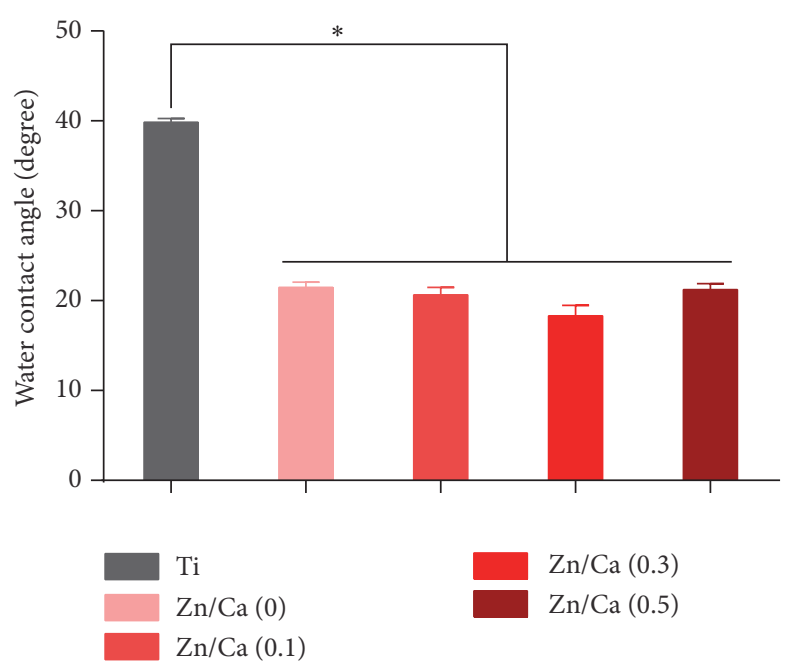

Figure 2: Water contact angles of samples Ti, $\mathrm{Zn} / \mathrm{Ca}(0), \mathrm{Zn} / \mathrm{Ca}(0.1), \mathrm{Zn} / \mathrm{Ca}(0.3)$, and $\mathrm{Zn} / \mathrm{Ca}(0.5)$ at $25^{\circ} \mathrm{C} .{ }^{*} p<0.05 ; n=6$ for each sample.

of $\mathrm{HA}$, not $\mathrm{TiO}_{2}$. In contrast, $\mathrm{Ca}_{2} \mathrm{ZnSi}_{2} \mathrm{O}_{7}$, a $\mathrm{Zn}$-modified $\mathrm{Ca}-\mathrm{Si}$ coating, has been reported as a biometrical substrate for bone-related cell culture. However, the potential slow release of $\mathrm{Zn}^{2+}$ was not evaluated. We found that $\mathrm{Zn}$ can promote osteoblast proliferation and differentiation compared to on pure $\mathrm{Ca}-\mathrm{Si}$ based coatings. $\mathrm{Zn}$ may have been released slowly from the hybrid nanocoating, playing an important role in the effect on osteoblasts.

3.3. Behaviors of Cells on Nanocoatings. Some materials can affect osteoclasts when stimulating osteoblasts because of the dynamic balance of these cells $[13,14]$. MC3T3-E1 and RAW 264.7 cells, as cell models of osteoblasts and osteoclasts, respectively, were employed in this study and cultivated on the surface of all samples for proliferation analysis. MC3T3E1 cells and RAW 264.7 cells grew in 7 days. As shown in
Figures 4 and 5, the numbers of RAW 264.7 cells on all nanocoatings were similar, containing $\mathrm{Zn} / \mathrm{Ca}(0), \mathrm{Zn} / \mathrm{Ca}$ (0.1), $\mathrm{Zn} / \mathrm{Ca}(0.3)$, and $\mathrm{Zn} / \mathrm{Ca}(0.5)$, which were lower than on pure Ti discs at day 3. At day 7 , the number of cells increased as $\mathrm{Zn}$ content increased and then decreased at a $\mathrm{Zn} / \mathrm{Ca}$ ratio of 0.3. Attentively, the samples without $\mathrm{Zn}, \mathrm{Ti}$, and $\mathrm{Zn} / \mathrm{Ca}(0)$ showed better cell growth, revealing how the nanocoatings with the Zn element inhibited osteoclast through inhibitory or biphasic effects of $\mathrm{Zn}$ on osteoclastic bone resorption [9]. Moreover, the formation of multinucleated cells is the main feature of osteoclast-like cells. Some multinucleated cells were found in samples $\mathrm{Ti}$ and $\mathrm{Zn} / \mathrm{Ca}(0)$, indicated by asterisk in Figure 4. However, MC3T3-E1 cells showed the opposite growth tendency for different nanocoatings of $\mathrm{Zn} / \mathrm{Ca}$. The order of cell viability was $\mathrm{Ti}<\mathrm{Zn} / \mathrm{Ca}(0)<\mathrm{Zn} / \mathrm{Ca}(0.1)<$ $\mathrm{Zn} / \mathrm{Ca}(0.3)$ or $\mathrm{Zn} / \mathrm{Ca}(0.5)$ at day 3. The viability of MC3T3$\mathrm{E} 1$ cells grown on $\mathrm{Zn} / \mathrm{Ca}(0.3)$ was the highest in all samples. 


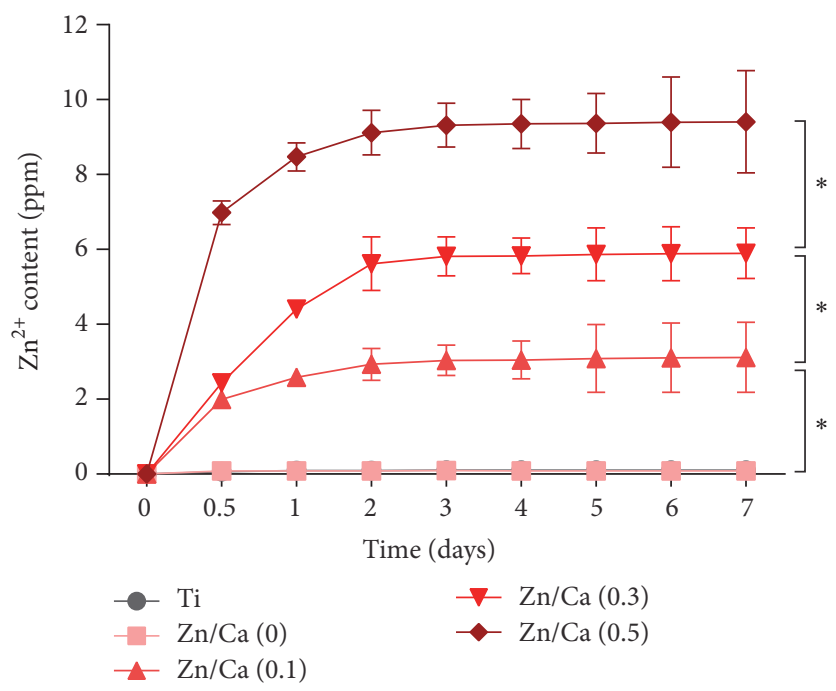

Figure 3: Curves of accumulated $\mathrm{Ca}^{2+}$ and $\mathrm{Zn}^{2+}$ released from $\mathrm{Ti}, \mathrm{Zn} / \mathrm{Ca}(0), \mathrm{Zn} / \mathrm{Ca}(0.1), \mathrm{Zn} / \mathrm{Ca}(0.3)$, and $\mathrm{Zn} / \mathrm{Ca}(0.5)$ in 7 days. ${ }^{*} p<0.05$; $n=4$ for each sample.
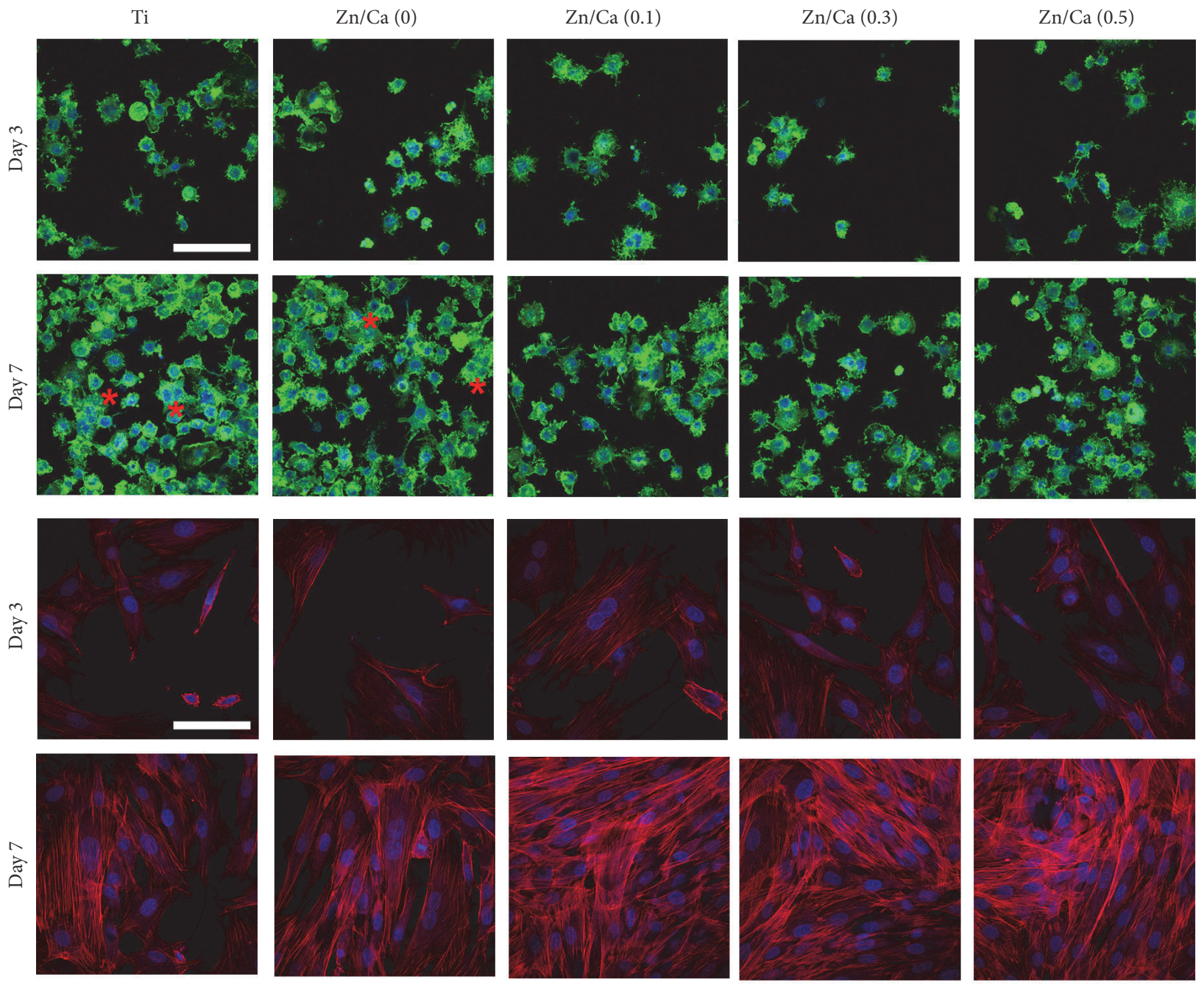

Figure 4: CLSM images of RAW 264.7 cells and MC3T3-E1 cells grown on Ti, $\mathrm{Zn} / \mathrm{Ca}(0), \mathrm{Zn} / \mathrm{Ca}(0.1), \mathrm{Zn} / \mathrm{Ca}(0.3)$, and $\mathrm{Zn} / \mathrm{Ca}(0.5)$ at day 3 and day 7. The bar is $100 \mu \mathrm{m}$. The red asterisks indicate the multinucleated cells for osteoclast differentiation of RAW 264.7 cells. 


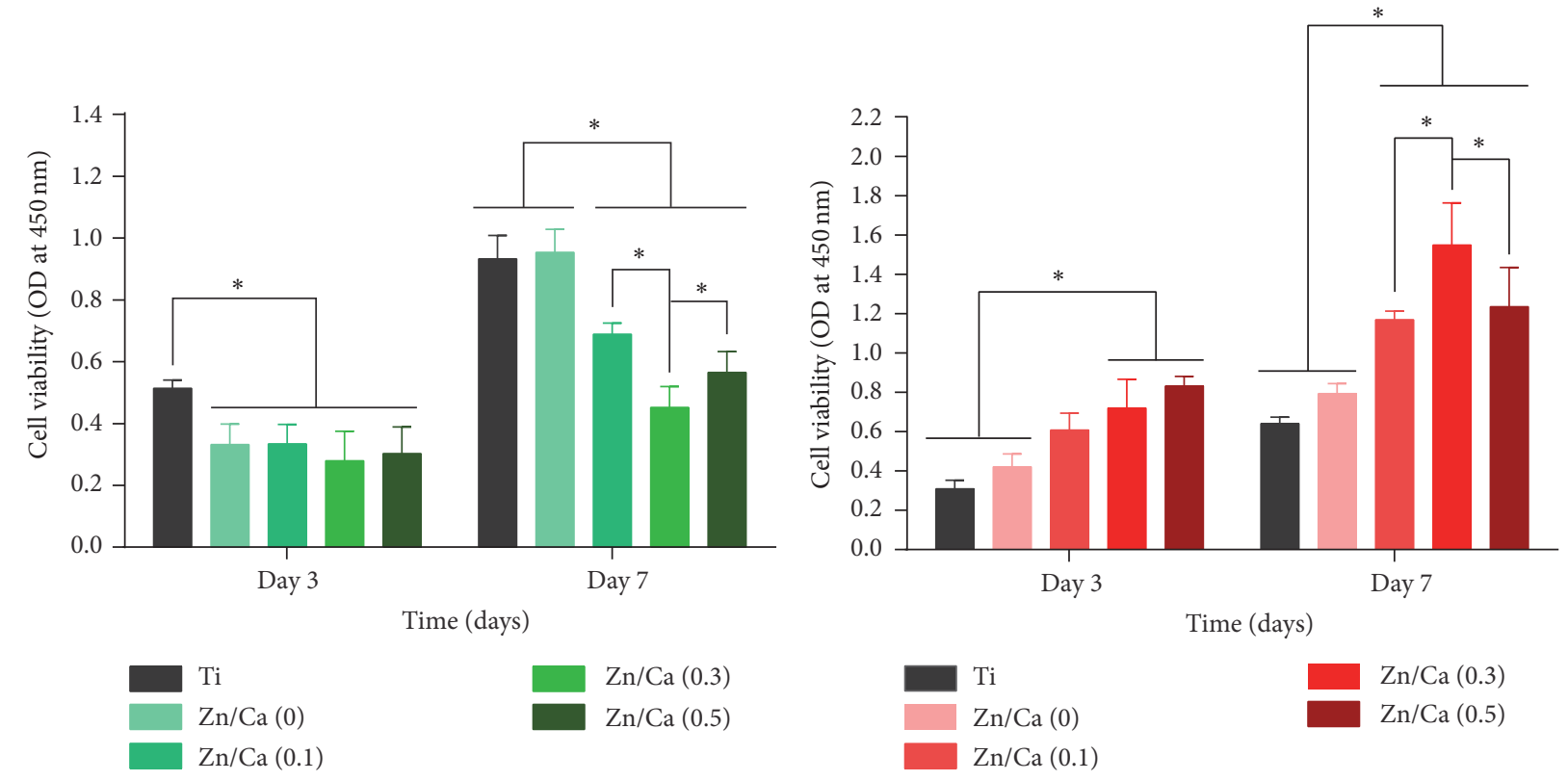

(a)

(b)

Figure 5: The CCK-8 assay of (a) RAW 264.7 cells and (b) MC3T3-E1 cells grown on Ti, Zn/Ca (0), Zn/Ca (0.1), Zn/Ca (0.3), and Zn/Ca (0.5) at day 3 and day 7 , respectively. ${ }^{*} p<0.05 ; n=4$ for each sample.
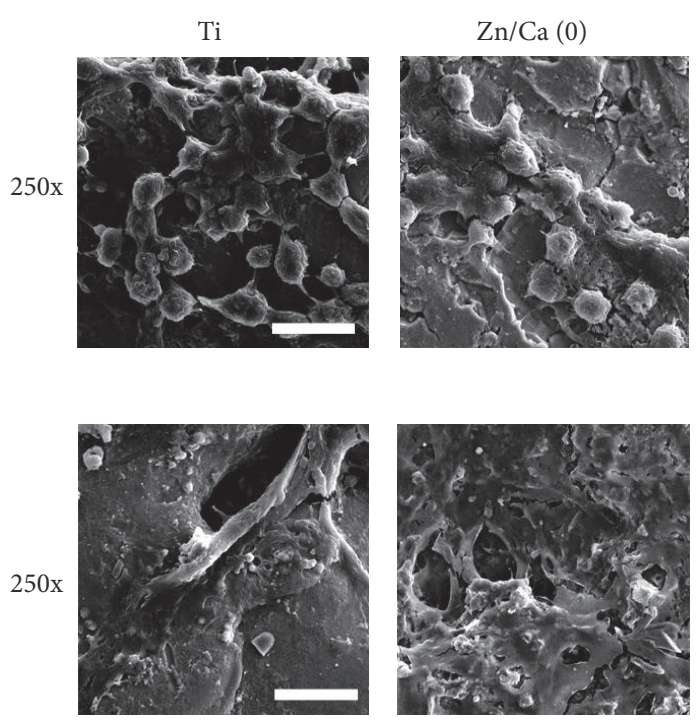
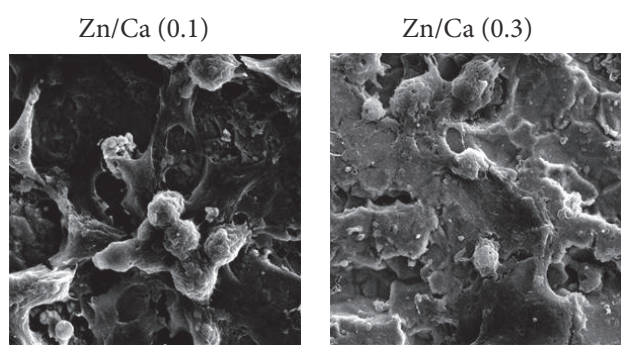

(a)
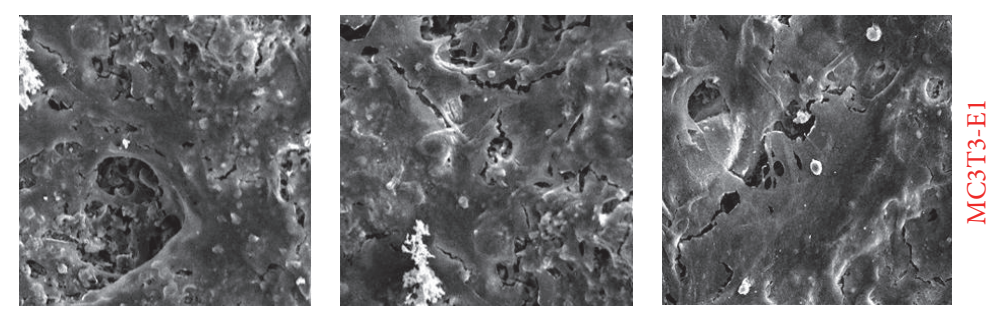

(b)

FIGURE 6: SEM images of RAW 264.7 cells (a) and MC3T3-E1 cells (b) grown on Ti, Zn/Ca (0), Zn/Ca (0.1), Zn/Ca (0.3), and Zn/Ca (0.5) at day 7. The bar is $50 \mu \mathrm{m}$.

In contrast to RAW 264.7 cells, MC3T3-E1 cells on the discs with $\mathrm{Zn}$ nanocoating showed higher viability than samples without $\mathrm{Zn}$, similarly to our previous results [11]. Differences in cell number and morphology were determined by SEM as shown in Figure 6. A larger number of normal RAW 264.7 cells was found on samples $\mathrm{Ti}$ and $\mathrm{Zn} / \mathrm{Ca}(0)$. In contrast, MC3T3-E1 cells preferred to adhere and grew well on $\mathrm{Zn} / \mathrm{Ca}$ (0.1), $\mathrm{Zn} / \mathrm{Ca}(0.3)$, and $\mathrm{Zn} / \mathrm{Ca}(0.5)$.
These results show that nanocoating with higher $\mathrm{Zn}$ content promotes osteoblasts while inhibiting osteoclasts. Changes in the shape and number of MC3T3-E1 and RAW 264.7 cells were also observed by confocal laser scanning microscopy as shown in Figure 4 and SEM in Figure 6.

With in vitro release test, we discovered the accumulative release curves of $\mathrm{Zn}^{2+}$ for all nanocoatings samples started to be steady at day 3 . Hence, day 3 is an important time point 


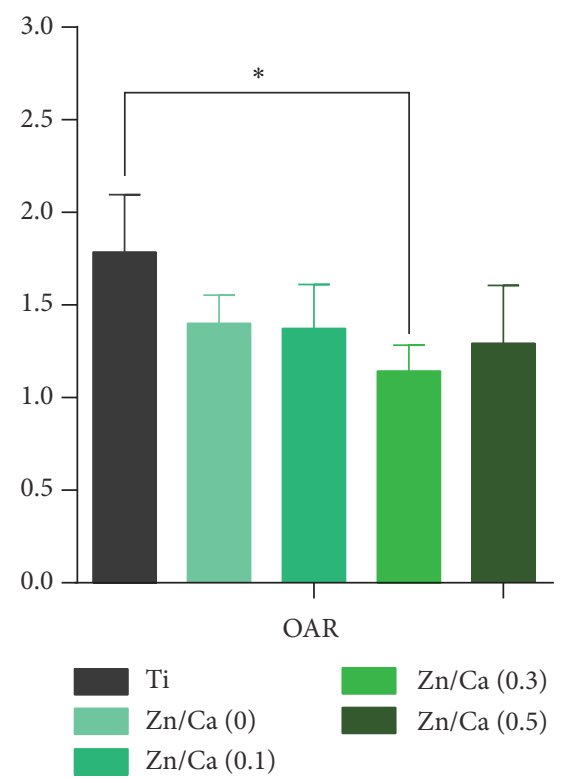

(a)

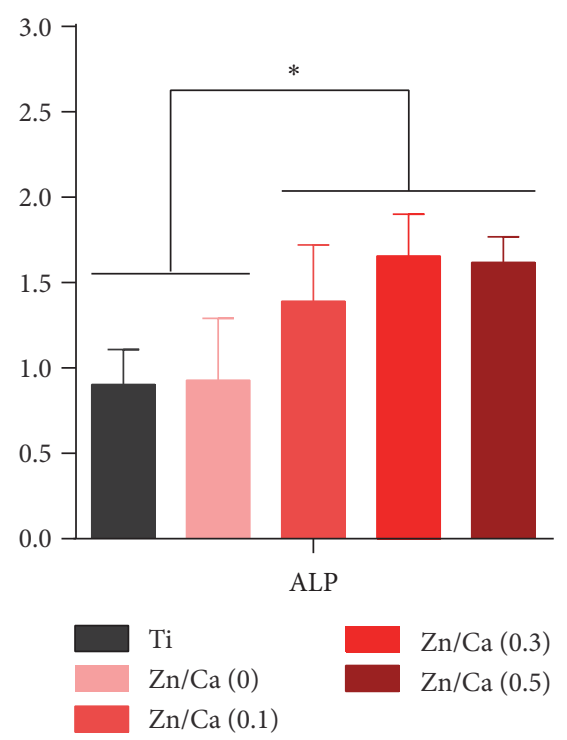

(d)

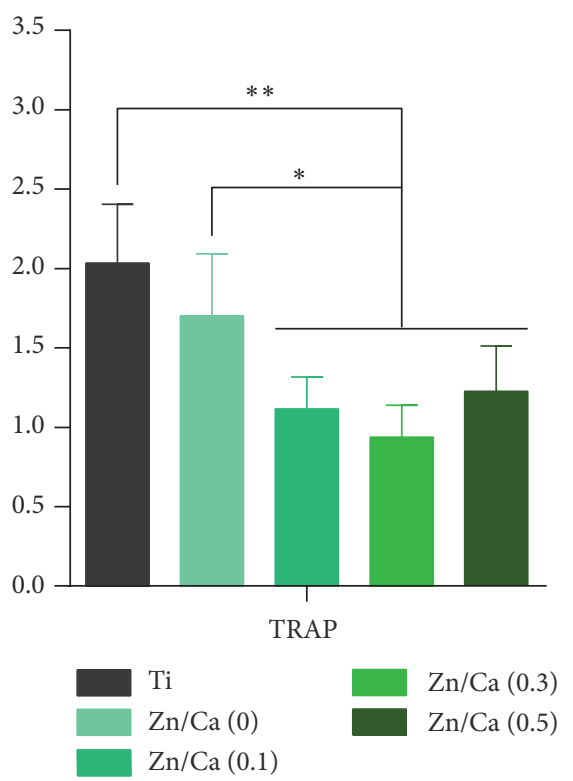

(b)

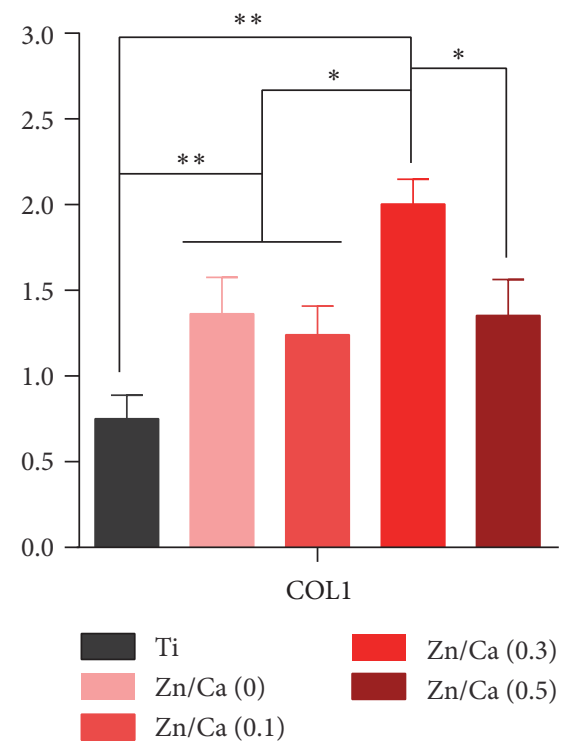

(e)

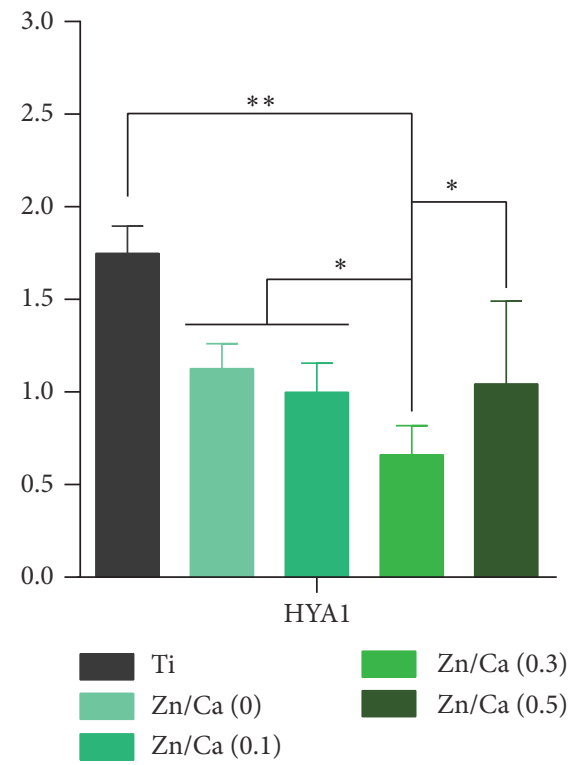

(c)

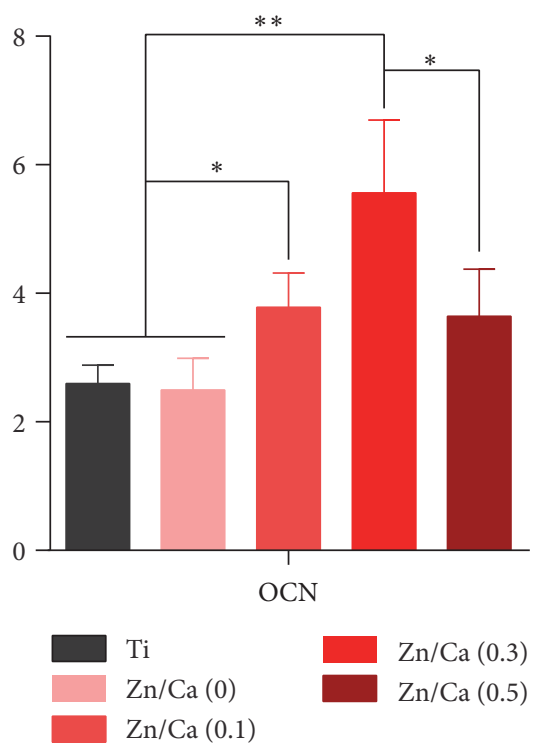

(f)

FIGURE 7: Real-time quantitative PCR analysis of gene expression for osteoclastic marker genes in RAW 264.7 cells and osteogenic marker genes in MC3T3-E1 cells grown on $\mathrm{Ti}, \mathrm{Zn} / \mathrm{Ca}(0), \mathrm{Zn} / \mathrm{Ca}(0.1), \mathrm{Zn} / \mathrm{Ca}(0.3)$, and $\mathrm{Zn} / \mathrm{Ca}(0.5)$ at day 7 , respectively. ${ }^{*} p<0.05$; ${ }^{* *} p<0.01$; $n=3$ for each sample. The $y$-axis represented the relative expression $\left(2^{-\Delta \mathrm{CT}}\right)$ normalized to expression level. Osteoclastic marker genes: (a) osteoclast-associated receptor (OAR), (b) tartrate-resistant acid phosphatase (TRAP), and (c) hyaluronoglucosaminidase 1 (HYA1). Osteogenic marker genes: (d) alkaline phosphatase (ALP), (e) collagen type-1 (COL1), and (f) osteocalcin (OCN).

for cells in this study. In early stage, $\mathrm{Zn}^{2+}$ concentration was lacking; the concentration is maximum for cell growth for starting at day 3. Maybe it is the main reason that there is no remarkable difference of cells in all nanocoatings samples at day 3; however it was changed to be remarkable at day 7.

3.4. Response of Cells on Nanocoatings. To explore the inhibition of osteoclastic differentiation of $\mathrm{Ca}_{2} \mathrm{ZnSi}_{2} \mathrm{O}_{7}$ ceramic nanocoating with different $\mathrm{Zn} / \mathrm{Ca}$ ratios, the expression of three relative genes, OAR, TRAP, and HYA1, was assessed by RT-qPCR. In Figures 7(a)-7(c), gene expression in RAW 264.7 cells was downregulated with increasing $\mathrm{Zn}$ in the nanocoating. The effect of sample $\mathrm{Zn} / \mathrm{Ca}(0.3)$ was most significant, which was lower than $\mathrm{Zn} / \mathrm{Ca}(0), \mathrm{Zn} / \mathrm{Ca}(0.1)$, $\mathrm{Zn} / \mathrm{Ca}(0.5)$ and Ti discs for any osteoclastic genes. Because of the lack of $\mathrm{Zn}$, the $\mathrm{Zn} / \mathrm{Ca}$ (0) (i.e., $\mathrm{CaSiO}_{3}$ nanocoating) showed similar expression of OAR and HYAl on the Ti discs, but TRAP expression was slightly higher than on Ti. This demonstrates that $\mathrm{Zn}$-loading of the nanocoating inhibited RAW 264.7 cell differentiation by affecting mRNA expression 
related to the osteoclastogenic response, particularly for $\mathrm{Zn} / \mathrm{Ca}$ (0.3). On the contrary, overmuch $\mathrm{Zn}$, such as sample $\mathrm{Zn} / \mathrm{Ca}$ (0.5), could also affect related gene expression, but not best. When RANKL binds to RANK, various signaling pathways (e.g., OAR, TRAP, and HYA1) in RAW 264.7 cells can be rapidly activated to facilitate osteoclast differentiation. RANKL can stimulate some transcription factors, such as AP-1, through mitogen-activated protein kinase (MAPK) activation, and NF-kappaB through IkappaB kinase (IKK) activation [23]. Hence, these pathways play an important role in osteoclastogenesis. In our study, suppression of these signaling pathways was thought to inhibit osteoclast differentiation on the $\mathrm{Ca}_{2} \mathrm{ZnSi}_{2} \mathrm{O}_{7}$ ceramic nanocoating. However, the inhibition mechanism of $\mathrm{Zn}$ in osteoclast differentiation requires further analysis $[2,12]$.

To further evaluate the mechanism of the promotion of osteogenic differentiation of MC3T3-E1 cells, the expression of related genes was also evaluated. As shown in Figures 7(d)-7(f), sample $\mathrm{Zn} / \mathrm{Ca}$ (0.3), which was modified by a ceramic nanocoating at a $0.3 \mathrm{Zn} / \mathrm{Ca}$ ratio, always showed the highest mRNA expression of ALP, COL-1, and OCN. In addition, samples loaded with higher or lower $\mathrm{Zn}$ content than $\mathrm{Zn} / \mathrm{Ca}(0.3)$, that is, $\mathrm{Zn} / \mathrm{Ca}(0.1)$ and $\mathrm{Zn} / \mathrm{Ca}(0.5)$, showed higher expression of ALP and OCN in MC3T3-E1 cells than in samples $\mathrm{Ti}$ and $\mathrm{Zn} / \mathrm{Ca}(0)$. This result is in accordance with previous results of ALP gene regulation, which indicated that the $\mathrm{Ca}_{2} \mathrm{ZnSi}_{2} \mathrm{O}_{7}$ nanocoating has a greater ability to stimulate preosteoblast differentiation compared to $\mathrm{CaSiO}_{3}$ nanocoating and $\mathrm{Ti}$ discs. And ALP is a $\mathrm{Zn}$-dependent enzyme, illustrated in past reports, while others were secreted solely by osteoblasts and thought to play a role in cell mineralization and calcium ion homeostasis. In addition, ALP acts as initiators of biological mineralization [24, 25], which is very important for osteogenic differentiation. The results of peak-tendency for osteoblast of mRNA expression also explain why the expression of these genes was changed by $\mathrm{Zn}$ content in a dose-dependent manner, with the $\mathrm{Zn} / \mathrm{Ca}$ ratio of 0.3 showing the best results.

Interestingly, two profiles of relevant mRNA expression, the peak-tendency for osteoblast and valley-tendency for osteoclasts, were complementary. Thus, the $\mathrm{Zn}$ content in the $\mathrm{Ca}_{2} \mathrm{ZnSi}_{2} \mathrm{O}_{7}$ nanocoating may simultaneously regulate osteogenic-osteoclastic differentiation because of the slow release of introduced $\mathrm{Zn}$.

\section{Conclusions}

By comparison of the $\mathrm{Ti}$ surface, the morphology of $\mathrm{Ca}_{2} \mathrm{ZnSi}_{2} \mathrm{O}_{7}$ ceramic nanocoating with $\mathrm{Zn} / \mathrm{Ca}(0.1), \mathrm{Zn} / \mathrm{Ca}$ (0.3), and $\mathrm{Zn} / \mathrm{Ca}(0.5)$ was rough and mixed with some nanoparticles or aggregations, which differed from $\mathrm{Zn} / \mathrm{Ca}(0)$ $\left(\mathrm{CaSiO}_{3}\right.$ nanocoating) and Ti. Additionally, the $\mathrm{Ca}_{2} \mathrm{ZnSi}_{2} \mathrm{O}_{7}$ ceramic nanocoating showed a typical slow release of $\mathrm{Zn}^{2+}$ with a burst release during the initial $12 \mathrm{~h}$. MC3T3-E1 cells showed the highest cell viability on sample $\mathrm{Zn} / \mathrm{Ca}(0.3)$, and all the expressions of the ALP, COL-1, and OCN genes involved in osteogenic differentiation were upregulated. In contrast, for $\mathrm{Zn} / \mathrm{Ca}$ (0.3), RAW 264.7 cells showed the lowest cell viability and inhibited the osteoclastic gene expressions of OAR, TRAP, and HYA1. In summary, the optimal ZnCa ratio of 0.3 in the $\mathrm{Ca}_{2} \mathrm{ZnSi}_{2} \mathrm{O}_{7}$ ceramic nanocoating on Ti with $\mathrm{Zn}^{2+}$ slow release may have osteoblast-promoting and osteoclast-inhibiting effects to form a dynamic balance between osteoblasts/osteoclasts.

\section{Disclosure}

Jiangming Yu and Lizhang $\mathrm{Xu}$ are co-first authors.

\section{Competing Interests}

All authors declare that there is no conflict of interests regarding the publication of this paper.

\section{Acknowledgments}

The research was supported by the National Natural Science Foundation of China (Grant no. 81301537).

\section{References}

[1] S. Ni, J. Chang, L. Chou, and W. Zhai, "Comparison of osteoblast-like cell responses to calcium silicate and tricalcium phosphate creamics in vitro," Journal of Biomedical Materials Research-Part B Applied Biomaterials, vol. 80, no. 1, pp. 174183, 2007.

[2] X. Liu, S. Tao, and C. Ding, "Bioactivity of plasma sprayed dicalcium silicate coatings," Biomaterials, vol. 23, no. 3, pp. 963968, 2002.

[3] C. Wu, J. Chang, J. Wang, S. Ni, and W. Zhai, "Preparation and characteristics of a calcium magnesium silicate (bredigite) bioactive ceramic," Biomaterials, vol. 26, no. 16, pp. 2925-2931, 2005.

[4] M. Schumacher, A. Lode, A. Helth, and M. Gelinsky, "A novel strontium(II)-modified calcium phosphate bone cement stimulates human-bone-marrow-derived mesenchymal stem cell proliferation and osteogenic differentiation in vitro," Acta Biomaterialia, vol. 9, no. 12, pp. 9547-9557, 2013.

[5] C. Wu, Y. Ramaswamy, D. Kwik, and H. Zreiqat, "The effect of strontium incorporation into $\mathrm{CaSiO}_{3}$ ceramics on their physical and biological properties," Biomaterials, vol. 28, no. 21, pp. 31713181, 2007.

[6] Y. Ramaswamy, C. Wu, A. Van Hummel, V. Combes, G. Grau, and H. Zreiqat, "The responses of osteoblasts, osteoclasts and endothelial cells to zirconium modified calcium-silicate-based ceramic," Biomaterials, vol. 29, no. 33, pp. 4392-4402, 2008.

[7] C. Wu, Y. Ramaswamy, A. Soeparto, and H. Zreiqat, "Incorporation of titanium into calcium silicate improved their chemical stability and biological properties," Journal of Biomedical Materials Research - Part A, vol. 86, no. 2, pp. 402-410, 2008.

[8] H. Tapiero and K. D. Tew, "Trace elements in human physiology and pathology: zinc and metallothioneins," Biomedicine and Pharmacotherapy, vol. 57, no. 9, pp. 399-411, 2003.

[9] M. Yamaguchi, H. Oishi, and Y. Suketa, "Stimulatory effect of zinc on bone formation in tissue culture," Biochemical Pharmacology, vol. 36, no. 22, pp. 4007-4012, 1987.

[10] W. Windisch, U. Wher, W. Rambeck, and R. Erben, "Effect of $\mathrm{Zn}$ deficiency and subsequent $\mathrm{Zn}$ repletion on bone mineral composition and markers of bone tissue metabolism in 
65Zn-labelled, young-adult rats," Journal of Animal Physiology and Animal Nutrition, vol. 86, no. 7-8, pp. 214-221, 2002.

[11] J. Yu, K. Li, X. Zheng, D. He, X. Ye, and M. Wang, "In Vitro and In Vivo Evaluation of Zinc-Modified Ca-Si-Based Ceramic Coating for Bone Implants," PLoS ONE, vol. 8, no. 3, Article ID e57564, 2013.

[12] K. Li, J. Yu, Y. Xie, L. Huang, X. Ye, and X. Zheng, "Chemical stability and antimicrobial activity of plasma sprayed bioactive $\mathrm{Ca}_{2} \mathrm{ZnSi}_{2} \mathrm{O}_{7}$ coating," Journal of Materials Science: Materials in Medicine, vol. 22, no. 12, pp. 2781-2789, 2011.

[13] C. V. Gurban and O. Mederle, "The OPG/RANKL system and zinc ions are promoters of bone remodeling by osteoblast proliferation in postmenopausal osteoporosis," Romanian Journal of Morphology and Embryology, vol. 52, no. 3, supplement, pp. 1113-1119, 2011.

[14] M. Satué, M. D. M. Arriero, M. Monjo, and J. M. Ramis, "Quercitrin and Taxifolin stimulate osteoblast differentiation in MC3T3-E1 cells and inhibit osteoclastogenesis in RAW 264.7 cells," Biochemical Pharmacology, vol. 86, no. 10, pp. 1476-1486, 2013.

[15] Y. C. Chai, G. Kerckhofs, S. J. Roberts et al., "Ectopic bone formation by $3 \mathrm{D}$ porous calcium phosphate-Ti6Al4V hybrids produced by perfusion electrodeposition," Biomaterials, vol. 33, no. 16, pp. 4044-4058, 2012.

[16] H. Güleryüz and H. Çimenoğlu, "Effect of thermal oxidation on corrosion and corrosion-wear behaviour of a Ti-6Al-4V alloy," Biomaterials, vol. 25, no. 16, pp. 3325-3333, 2004.

[17] E. H. Fragal, T. S. P. Cellet, V. H. Fragal et al., "Hybrid materials for bone tissue engineering from biomimetic growth of hydroxiapatite on cellulose nanowhiskers," Carbohydrate Polymers, vol. 152, pp. 734-746, 2016.

[18] H. Shin, S. Jo, and A. G. Mikos, "Biomimetic materials for tissue engineering," Biomaterials, vol. 24, no. 24, pp. 4353-4364, 2003.

[19] A. Valanezhad, K. Tsuru, and K. Ishikawa, "Fabrication of strongly attached hydroxyapatite coating on titanium by hydrothermal treatment of $\mathrm{Ti}-\mathrm{Zn}-\mathrm{PO}_{4}$ coated titanium in $\mathrm{CaCl}_{2}$ solution," Journal of Materials Science: Materials in Medicine, vol. 26, no. 7, article 212, 2015.

[20] Y.-W. Shang, W. Zhang, J. He, D.-N. Wang, M. Zhong, and B.H. Zhao, "Study of relationship between $(\mathrm{Ca}+\mathrm{Zn}) / \mathrm{P}$ of pure titanium surface coating and biological activity of osteoblasts," Shanghai kou qiang yi xue = Shanghai journal of stomatology, vol. 24, no. 1, pp. 46-51, 2015.

[21] T. Boonfueng, L. Axe, N. Yee, D. Hahn, and P. K. Ndiba, "Zn sorption mechanisms onto sheathed Leptothrix discophora and the impact of the nanoparticulate biogenic Mn oxide coating," Journal of Colloid and Interface Science, vol. 333, no. 2, pp. 439447, 2009.

[22] J. Y. Zhang, H. J. Ai, and M. Qi, "Osteoblast growth on the surface of porous $\mathrm{Zn}$-containing $\mathrm{HA} / \mathrm{TiO}_{2}$ hybrid coatings on Ti substrate by MAO plus sol-gel methods," Surface and Coatings Technology, vol. 228, no. 1, pp. S202-S205, 2013.

[23] J. Mizukami, G. Takaesu, H. Akatsuka et al., "Receptor activator of NF- $\kappa$ B ligand (RANKL) activates TAK1 mitogen-activated protein kinase kinase kinase through a signaling complex containing RANK, TAB2, and TRAF6," Molecular and Cellular Biology, vol. 22, no. 4, pp. 992-1000, 2002.

[24] N. Ohara, N. Ohara, K. Yanagiguchi, S. Yamada, I. L. Viloria, and Y. Hayashi, "Expression of alkaline phosphatase induces rapid and artificial mineralization in specific transformed Escherichia coli," New Microbiologica, vol. 25, no. 1, pp. 107-110, 2002.
[25] H. S. Sandhu and S. S. Jande, "Investigations of alkaline phosphatase $\mathrm{Ca}+2$-ATPase and $\mathrm{Na}+\mathrm{K}+$-ATPase during Beta-APNinduced initial bone mineralization inhibition," Acta Anatomica, vol. 112, no. 3, pp. 242-248, 1982. 

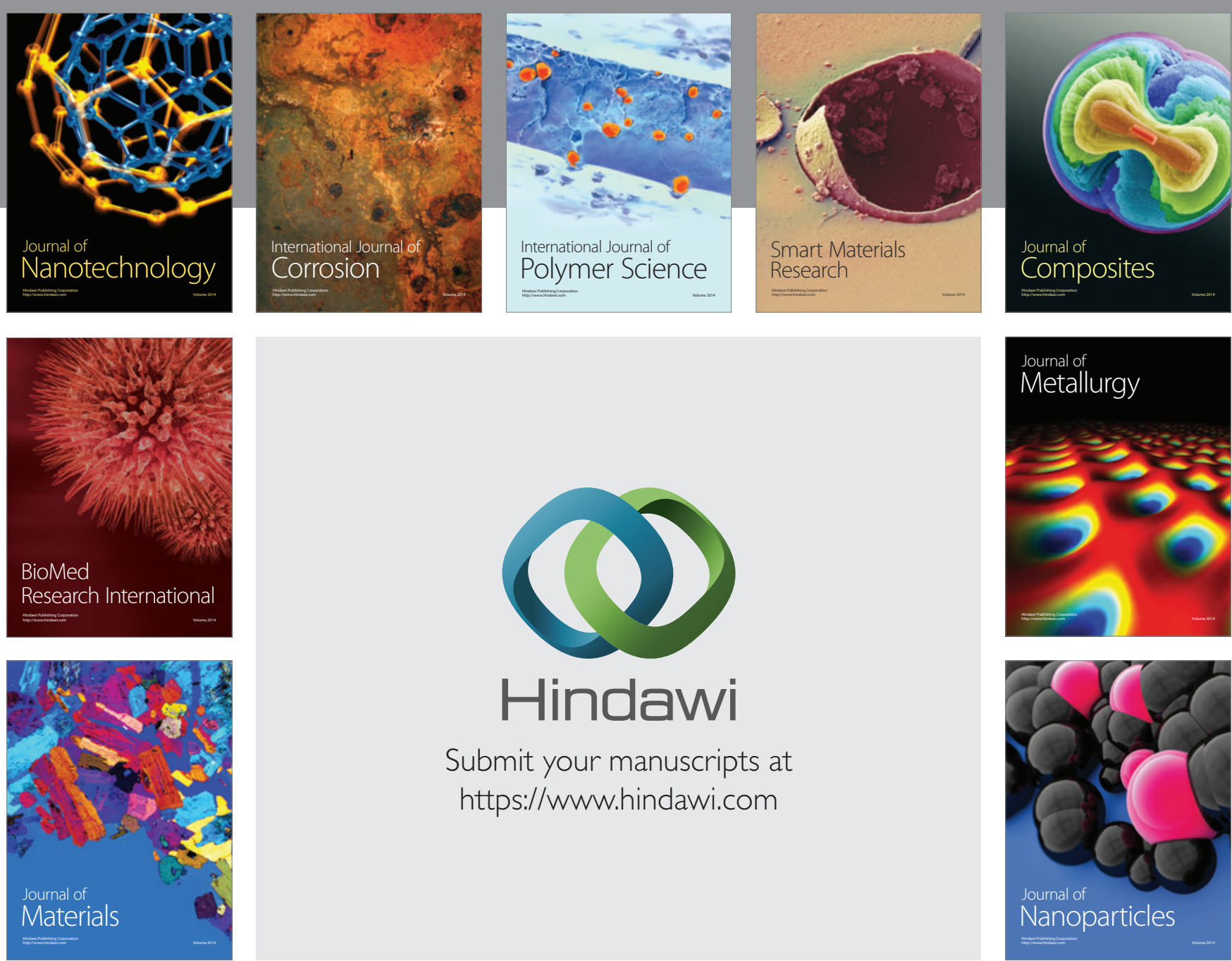

\section{Hindawi}

Submit your manuscripts at

https://www.hindawi.com

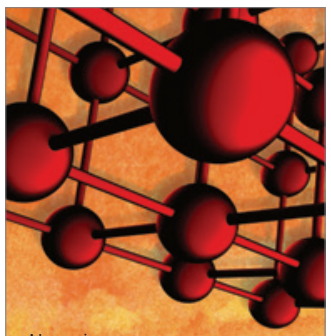

Materials Science and Engineering
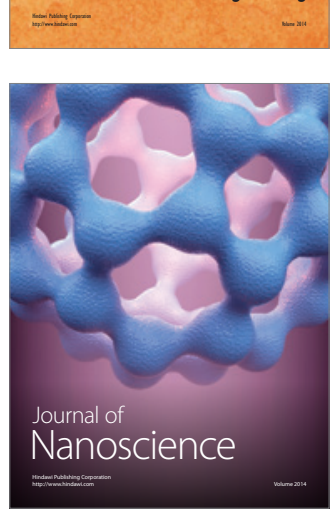
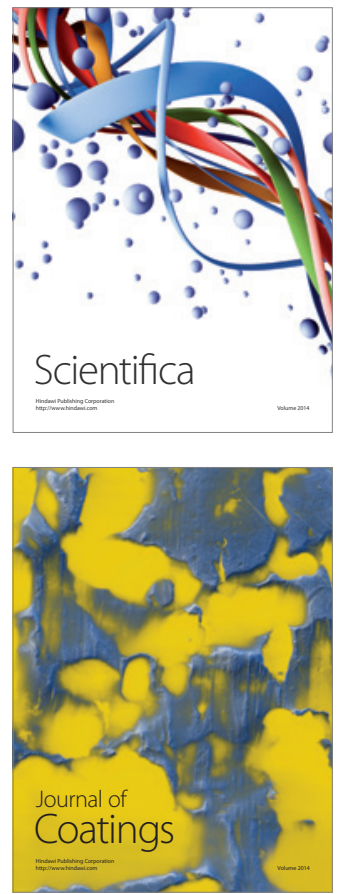
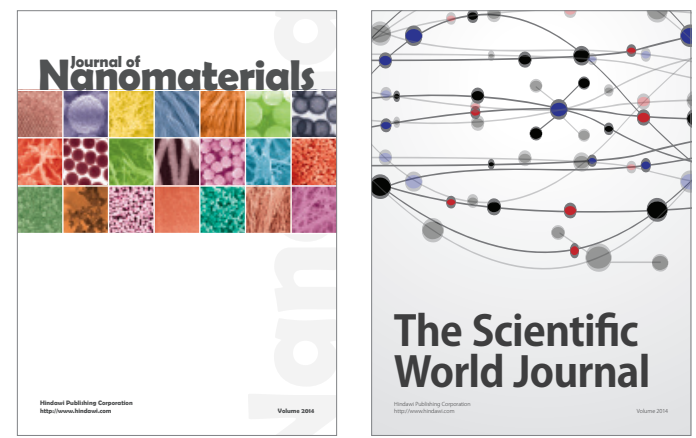

The Scientific World Journal
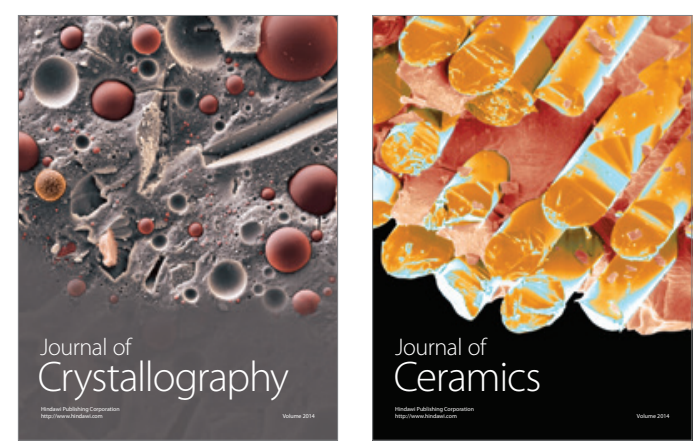
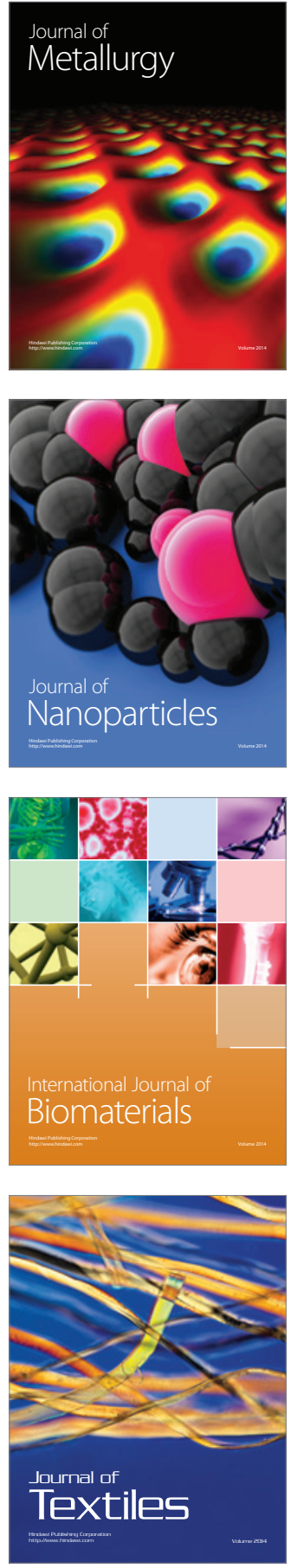